\title{
Experts Valuating the Climate Change Policies in Greece: Self-Interested Versus Ethically Motivated Values
}

\author{
Vasileios Markantonis ${ }^{1,2}$ \& Kostas Bithas $^{3}$ \\ ${ }^{1}$ Joint Research Center of the European Commission (JRC), Ispra, Italy \\ ${ }^{2}$ Research Institute of Urban Environment and Human Resources (UEHR), Panteion University, Athens, Greece \\ ${ }^{3}$ Faculty of Economics and Regional Development, Panteion University, Athens, Greece \\ Correspondence: Vasileios Markantonis, Joint Research Center of the European Commission (JRC), Ispra, Italy. \\ Tel: 39-332-783-731.E-mail: vasileios.markantonis@jrc.ec.europa.eu
}

Received: June 25, 2014 Accepted: July 24, 2014 Online Published: September 9, 2014

doi:10.5539/enrr.v4n4p109 URL: http://dx.doi.org/10.5539/enrr.v4n4p109

\begin{abstract}
Understanding and estimating the climate change costs has been in focus of the scientific community in the last years, whereas several studies are dealing with this challenging issue. In this context, the present paper aims at valuating the climate change mitigation and adaptation measures in Greece. To achieve that, we carried out a contingent valuation survey. In addition it explores the coexistence of ethically motivated values and self-interested values held by Greek climate experts, a condition in economics underlying the existence of the "Bergson-Tintner-Samuelson (BTS) value formulation effect". This is an experimental attempt in recent valuation literature and carries significant implications for the valuation issue and its policy implications. The results indicate that ethically motivated values of crucial environmental functions such as climate far exceed the individualistic ones. Furthermore, the coexistence of public ethically-based values alongside self-interested ones supports earlier findings in the literature and indicates that solely self-interested individual values do not reflect the real welfare contribution of crucial environmental functions and, therefore, should not form the exclusive guide for environmental policy.
\end{abstract}

Keywords: climate change costs, environmental valuation, mitigation and adaptation, experts' preferences

\section{Introduction}

According to the IPCC 5th Assessment Report, Greece, as a geographical part of the Mediterranean, appears to be an area highly vulnerable to the effects of climate change. In particular, the Report marks out Southern Greece as one of the regions potentially most affected, an evolution expressed mainly through increased incidence of heat waves and droughts (IPCC, 2013). The severity of those climate change impacts indicates the need for comprehensive mitigation and adaptation policy measures in Greece. In that context, the objective of this paper is twofold: First, to estimate the economic cost of climate change in Greece by applying a stated preferences survey to national climate experts. In designing our valuation framework we consider climate change as an indicative example of crucial environmental function. Second, the paper investigates the existence of the "Bergson-Tintner-Samuelson (BTS) value formulation effect" for climate change costs. This theory suggests that people hold two categories of values for public environmental goods: those motivated by private preferences and those driven by social preferences (Ami et al., 2014). In that respect the study investigates the dual values individual hold for crucial environmental functions. To our knowledge, it is the first time in recent literature that the BTS effect, which has significant implications for the valuation problem itself and for its policy relevance, has been investigated in connection with the valuation of environmental goods and services.

Our study carries out a Contingent Valuation (CV) survey (Spash \& Hanley, 1995) following widely applied methodology. We commence by discussing an essential strategic decision for the study, namely, the selection of participants in the survey. At this point, by defining "climate change experts" we include those individuals who have a proven professional knowledge and expertise in this scientific field. Our choice was to survey exclusively climate change experts so as to eliminate potential measurement biases and have the study focus on the investigation of two kinds of values held simultaneously by experts: self-interested and ethically motivated ones. The relative elimination of measurement biases is a necessary condition for placing emphasis on the evaluation of 
the moral incentives of preferences. An environmental policy that is based solely on self-interested values is ineffective when the environmental asset at hand inspires ethically motivated values as well. In this context, the ethically motivated values and preferences could be measured and taken into account by environmental policy.

On the other hand, the lack of sufficient knowledge and personal experience of "average" citizens in valuing complex environmental goods and services has become the subject of debate (Vatn \& Bromley, 1994). As Stevens et al. (1991) assert, "many respondents probably did not give the valuation question much thought". Those limitations result in various estimation biases (ordering and embedding effects, information biases, etc.) that have been addressed extensively in the relevant literature (Bishop \& Heberlein, 1979; Kahneman et al., 1990; Knetsch, 1995; Bergstrom et al., 1990; MacDonald \& Bowker, 1994; Brown \& Gregory, 1999; Kolstad \& Guzman, 1999). We consider eliminating the several existing biases to the maximum possible a necessary condition for tracing the co-existence of ethically motivated and self-interested values. This condition is quite crucial when valuating critical environmnental issues, such as climate change, that define the prospects of sustainability (Bithas, 2008). We consider as critical environmental functions those that provide a biologically 'safe operating space' for humanity (Rockstrom et al., 2009; Karr, 1991; Bithas, 2011). Clearly, critical environmental functions strongly concern the well-being of future generations. That characteristic may result in an inherent limitation of the ability of average citizens to value such functions and services. In contrast, experts are better informed on the scientific and technical aspects of crucial environment issues. Experts can, in this case, potentially offer a relatively more valid and authoritative evaluation, which could overcome some of the possible biases that arise in CV surveys of the general population.

Thus, limiting the survey to experts was a strategic methodological decision guided by the following characteristics of the climate change phenomenon:

- It concerns a crucial environmental function that defines the evolution of the earth's biosphere.

- It significantly affects the functioning of the economy and society.

- There are strong uncertainties regarding the function of the climate, climate change trends, and the impacts of climate change on society and the economy.

- Average citizens cannot understand the climate change phenomenon in detail because they lack previous experience and their opinions are influenced by current mass media trends.

- Although it directly concerns the present generation, it will profoundly determine the potentials of future generations due to its long-term impacts.

For multidimensional phenomena, like climate change, whose properties elude the perception of ordinary individuals, experts can offer a substantial contribution in shaping public policies. Experts can lead to the shaping of public choices and guide informed public decision making. Plato establishes the same argument in the Kriton dialogue (Woodruff, 2010; Peterson, 2011) where a democratic society acts and decides on the basis of knowledge, experience, and valid information which alter the knowledge of the average citizens; otherwise, the decision-makers may justify their decisions by invoking the essential ignorance of the average citizens. In the study of Van Houtven et al. (2014) experts' elicitations where combined with stated preferences methods to estimate ecosystem services values occurring from lake water quality improvement.

In any case, we do not assume that a valuation based on the experts' preferences is representative of the general population. However, we suggest this valuation as representative of the 'informed citizens' thereby overcoming the inherent limitation of the average citizens.

Furthermore, the present paper investigates the dual identity of the experts as self-interested individuals and as citizens motivated by ethical incentives, who evaluate crucial environmental goods. In that context, our paper analyses the Bergson-Tintner-Samuelson (BTS) value formulation effect according to which people hold two kinds of values for public environmental goods: values motivated by private preferences and values inspired by social preferences founded on moral duty and social commitment (Van Kooten \& Schmitz, 1992; Bergstrom et al., 1986; Bergson, 1938; Samuelson, 1977, 1981; Tintner, 1946). As citizens, respondents base their decisions on social welfare rather than their personal self-interested preferences when contributing to public goods (Nyborg, 2000; Sugden, 2005).

\section{The Methodological Framework}

\subsection{The Cost of Climate Change}

The direct valuation of the impacts of climate change is a difficult and uncertain process. Strong criticism has been leveled against efforts towards directly estimating climate change impacts at a macro level, such as the Stern 
Review (Stern, 2007). The Stern Review has provoked a debate (Weitzman, 2008; Nordhaus, 2008) with a focus on the selected discount rate and the valuation of future climate impacts. With regard to the latter, criticism focused on the underestimation of the non-market impacts on environmental functions and services (Sterner \& Persson, 2007; Neumayer, 2007). Moreover, the Stern Review has been criticized due to its advocating applying conventional methods of economic analysis to a problem for which they are unsuitable (Spash, 2007). In addition, Toman (2006) questions the empirical capacities and the implicit assumptions of climate change economics and develops a way for integrating economic analysis and public dialogue. Tol (2005) has used the results of twenty-eight published studies combined to form a probability density function for estimating the external costs of the carbon emissions and the uncertainties those estimates entail. In a later study (Tol, 2009), he reviewed the literature on the economic impacts of climate change, analyzing fourteen estimates of the total damage cost of climate change. In that study he perceives climate change as an externality that is unprecedentedly large, complex, and uncertain, where the most important among the non-estimated impacts include the indirect effects of climate change on economic development; large-scale biodiversity loss; low-probability; high-impact scenarios; climate change impact on violent conflict; and the impacts climate change will have beyond 2100.

Our approach avoids directly estimating climate change costs in Greece. Instead, it follows the alternative line of estimating the mitigation and adaptation costs required when dealing with climate change impacts at the national level. Taking into account the long-term duration of the climate change impacts, in tandem with the delay in implementing relevant policy measures, the present study estimates the national mitigation and adaptation costs at two time periods: at the present one and in 25 years, assuming that the current status of the relevant policies remains unchanged ("business as usual" policies). The specific adaptation and mitigation measure selected for this study were based on those indicated in the Stern Review (Stern, 2007), which was the prominent document, at the time of conducting the survey, setting the basis for the climate change costs.

The CV method is based on the assumption of standard economics that environmental assets and services can be treated identically to marketed goods for the purposes of valuation (Spash \& Hanley, 1995; Braden \& Kolstad, 1991). CV creates the conditions of a hypothetical market for non-marketed environmental assets. Although the results of the hypothetical markets have certain intrinsic shortcomings, they are accepted as a feasible valuation in the absence of more realistic estimates. In this context, Parks and Cowdy (2013) analyze the importance and challenges of traditional welfare methods, including stated preference, to estimate social values of crucial environmental functions, such as climate change.

Willingness-to-Pay (WTP) and Willingness-to-Accept (WTA) methods are expected to provide similar values. However, many differences do arise in practice either because of the presence of 'irrational choices' by respondents or because respondents may be unable or unwilling to offer meaningful valuations. Simultaneously, the income, wealth, and endowment effects may strongly influence the elicited values (Stevens et al., 1991; Whitehead \& Blomquist, 1991; Bergstrom et al., 1990; Coursey et al., 1987; Adamowicz et al., 1993). Although methodological reasons do exist for making a choice between WTP and WTA, the current literature is largely dominated by the WTP method.

With regard to the economics of climate change, several studies have used CV and other stated preferences methods to value the impacts of climate change on non-market goods. More specifically, Layton and Gardner (2000) used the conjoint analysis method to analyze the willingness to pay in order to prevent a long-term shift in the forest line caused by climate change. Berrens et al. (2004) applied a CV study to estimate American family willingness to pay in order to support the Kyoto Protocol. Fleischer and Sternberg (2005) used the choice modelling method to value the economic impact of global climate change on Mediterranean rangeland ecosystems. Riera et al. (2007) used CV to elicit values of climate change effects on Mediterranean shrublands and to estimate the costs of climate change mitigation programs. Moreover, Cameron (2004) applied a discrete-choice, stated preference method to estimate individual willingness to pay for climate change mitigation aspects.

\subsection{Self-Interested and Ethically Motivated, Social Values: The Bergson-Tintner-Samuelson Values Formulation}

In several cases, the extensive application of WTP has led to findings which, if one goes by economic theory, could not have been expected (Spash \& Hanley, 1995; Spash, 2000; Stevens et al., 1991; Whitehead \& Blomquist, 1991). The phenomenon that is most difficult to explain, in the context of standard welfare economics, is the coexistence of positive bids with lexicographic preferences. The standard approach predicts that an individual with lexicographic preferences accepts an absolute right for environmental services and must, therefore, refuse all monetary trade-offs. In that context, WTA tends to infinity while WTP approaches the individual's entire budget. In practice, individuals with lexicographic preferences for environmental services usually define WTP as zero, in protest against the monetary valuation. This is a stance expected in the context of standard theory. However, recent 
studies have identified positive 'moderate' bids in WTP by citizens who hold lexicographic preferences and hence attribute rights of protection to environmental functions and assets. That finding can hardly be explained in the context of standard welfare economics (Spash, 2000; Spash \& Hanley, 1995; Stevens et al., 1991).

In order to fathom the coexistence of ethically motivated and self-interested values, certain explanations have been developed. Spash accepts that rights-based respondents may express positive WTP values motivated by a risk-averse instinct for environmental functions (Spash, 2000). Stevens et al. (1991) suggest that positive bids can coexist with lexicographic preferences which are inspired by moral considerations. In this context, positive bids may express a desire for conservation, a 'good cause', irrespective of the value of the environmental function itself.

A systematic explanation can be traced through the Bergson-Tintner-Samuelson (BTS) value formulation (Bergson, 1938; Samuelson, 1977, 1981; Tintner, 1946). As adapted by Kohn (1993) and Stevens et al. (1993) for the valuation of environmental goods, the BTS value formulation suggests that people hold two categories of values for public environmental goods and services: values motivated by private preferences and values inspired by social preferences founded on moral duty and social commitment (Van Kooten \& Schmitz, 1992).

In that context, the present study aims at examining the existence of the BTS values formulation for climate change adaptation and mitigation measures and, hence, for climate impacts. Specifically the Greek climate experts were asked to provide two values:

a) The individual WTP for financing mitigation and adaptation measures. Here, the experts are expected to act as conventional individuals who express their WTP for the preservation or restoration of environmental functions (protecting climate and avoiding climate change impacts). Within this valuation framework there is an explicit trade-off between income and protection of the environmental functions and services.

b) The percentage of Greek GDP that should be allocated to mitigation and adaptation policies. That is the amount of public funding that should be allocated towards the preservation of the public good of climate and the avoidance of the corresponding 'public bads' (climate change impacts). In that second valuation, experts are expected to act as citizens and members of a society with an ethical commitment (Kohn, 1993; Stevens et al., 1993). Two separate valuations were requested: the present-day one and one in 25 years' time, under the assumption that the current status of climate change policy continues in effect. In both valuations, the GDP percentage is defined as an annual financial contribution for those adaptation and mitigation measures that are necessary in order to maintain the current level of social welfare and economic activities (2009 estimates).

The survey also contained a set of questions to evaluate opinions of the criticality of climate change at present and in the future. Eventually, forty-one national experts with a vast working experience in climate change were identified. They were affiliated with insitutions including research institutes, universities, non-governmental environmental organisations, public administration and environmental consultancies. This is a small sample in absolute terms. Nevertheless, it does contain all of the Greek experts in the relevant field. Eventually, 30 out of those 41 experts $(73 \%)$ agreed to participate in the survey, providing results concerning their preferences and values on the complex phenomenon of climate change. Data were collected by in-person interviews between June and November 2009.

\section{Findings and Analysis}

For the investigation of the Bergon-Tinter-Samuelson value formulation effect, that offers evidence of the co-existence of private and public preferences for climate change adaptation and mitigation measures, we should compare the individual WTP with the public contribution (percentance of GDP). For a meaningful comparison the public contribution will be converted to the household level. The experts indicate that an amount equal to $1.71 \%$ of GDP is the necessary public contribution. That is estimated at 3,881,700,000 euros, based on a GDP of 227 billion euros (Eurostat estimate for 2009). This is equivalent to a public contribution of 1358.60 euros for each of the 2,857,000 Greek households. On the other hand, the average individual WTP comes to 306.11 euros at the household level (Table 1). As a result, the public contribution at the household level is 4.4 times the individual contribution. It is evident that the disparity between individual (WTP) and public contributions is extremely wide. 
Table 1. Willingness-to-pay estimates of a national annual household fee for mitigation and adaptation costs

\begin{tabular}{llll}
\hline $\begin{array}{l}\text { If Yes, how much would you be willing to pay and how would you allocate } \\
\text { that payment to the specific mitigation and adaptation measures? }\end{array}$ & $\begin{array}{l}\text { Mean } \\
\text { WTP }(€)\end{array}$ & S.D. & \% \\
\hline Mitigation Total & $\mathbf{2 0 9 , 1 7}$ & $\mathbf{3 3 8 , 1 4}$ & $\mathbf{6 8 . 3 \%}$ \\
1 Improved energy efficiency & 50,64 & 96.36 & $16.5 \%$ \\
2 Promotion of new low-carbon technologies & 58,82 & 136,92 & $19.2 \%$ \\
3 Investment in renewable energy sources & 74,31 & 117,19 & $24.3 \%$ \\
4 Reduction of non-CO ${ }_{2}$ emissions (land use, farming, stockbreeding) & 25,01 & 33,82 & $8.2 \%$ \\
5 Other & 0,50 & 1,33 & $0.2 \%$ \\
Adaptation Total & $\mathbf{9 6 , 9 4}$ & $\mathbf{1 1 9 , 5 7}$ & $\mathbf{3 1 . 7 \%}$ \\
1. Restructuring the economy (new cultivations, eco-tourism, etc.) & 19,14 & 29,19 & $6.3 \%$ \\
2. Infrastructure for protection from natural hazards (floods, forest fires, etc.) & 16,32 & 20,06 & $5.3 \%$ \\
3. Infrastructure for the creation of new water reservoirs & 18,65 & 24,91 & $6.1 \%$ \\
4. Protection of the natural environment (rivers, threatened species, marine & 15,54 & 18,31 & $5.1 \%$ \\
ecosystems, etc.) & & & \\
5. Establishment of new institutional, regulatory and management structures & 17,49 & 26,56 & $5.7 \%$ \\
6. Reform of the healthcare system & 6,86 & 10,43 & $2.2 \%$ \\
7. Other (Climate change refugees) & 3,79 & 11,96 & $1.2 \%$ \\
TOTAL WTP for mitigation and adaptation & $\mathbf{3 0 6 , 1 1}$ & $\mathbf{4 4 5 , 4 6}$ & $\mathbf{1 0 0 . 0 \%}$ \\
\hline
\end{tabular}

This is strong evidence for the existence of a dual valuation described by to the BTS value formulation effect. The existence of the BTS effect is further supported by the data of Tables 2 and 3. Table 2 indicates that, in the WTP question, all the negative responses were the outcome of ethical reasoning. The 'zero protest bidders', according to Table 3, evaluate as significant the climate change impacts and, hence, the corresponding public good. According to Table 4 , the majority of 'zero protest bidders' proposes a public contribution between $0.5-1.5 \%$ of GDP today and $0.75 \%-3 \%$ in 25 years' time.

Table 2. Acceptance of the individual valuation scenario

\begin{tabular}{lll}
\hline $\begin{array}{l}\text { Would you be willing to pay a 'national annual household fee' for the } \\
\text { mitigation and adaptation of the climate change? }\end{array}$ & n \\
\hline No & 12 & $40.0 \%$ \\
a. Zero Protest Bids & 12 & \\
Justification of zero protest bids replies & \multicolumn{2}{l}{} \\
I don't believe in this approach & 6 & \\
It is an international issue and should be treated globally & 3 & \\
The state should pay for this & 3 & \\
b. Zero bids & 0 & \\
$Y E S$ & 18 & $60.0 \%$ \\
\hline
\end{tabular}


Table 3. Ranking the importance of climate change impacts at the national level

In your opinion, how important are the impacts of climate change in social, economic, and environmental terms at the national level?

\begin{tabular}{lllllllll}
\hline & \multicolumn{3}{l}{ Protest Zero bids respondents $(\mathrm{n}=12)$} & \multicolumn{2}{l}{ All respondents $(\mathrm{n}=30)$} \\
\hline Importance & \multicolumn{2}{l}{ Present } & \multicolumn{2}{l}{ In 25 years } & \multicolumn{2}{l}{ Present } & \multicolumn{2}{l}{ In 25 years } \\
\cline { 2 - 9 } & $\mathrm{n}$ & $\%$ & $\mathrm{n}$ & $\%$ & $\mathrm{n}$ & $\%$ & $\mathrm{n}$ & $\%$ \\
\hline $\begin{array}{l}\text { Not at } \\
\text { important }\end{array}$ & 0 & $0.0 \%$ & 0 & $0.0 \%$ & 0 & $0.0 \%$ & 0 & $0.0 \%$ \\
$\begin{array}{l}\text { Somewhat } \\
\text { important }\end{array}$ & 2 & $16.7 \%$ & 0 & $0.0 \%$ & 6 & $20.0 \%$ & 0 & $0.0 \%$ \\
$\begin{array}{l}\text { Important } \\
\text { Rather }\end{array}$ & 4 & $33.3 \%$ & 1 & $8.3 \%$ & 11 & $36.7 \%$ & 3 & $10.0 \%$ \\
important & 4 & $33.3 \%$ & 7 & $58.3 \%$ & 9 & $30.0 \%$ & 14 & $46.7 \%$ \\
Very important & 2 & $16.7 \%$ & 3 & $25.0 \%$ & 4 & $13.3 \%$ & 12 & $40.0 \%$ \\
I don't know & 0 & $0.0 \%$ & 1 & $8.4 \%$ & 0 & $0.0 \%$ & 1 & $3.3 \%$ \\
Total & 12 & $100 \%$ & 12 & $100 \%$ & 30 & $100 \%$ & 30 & $100 \%$ \\
\hline
\end{tabular}

Table 4. GDP contribution for mitigation and adaptation measures

\begin{tabular}{|c|c|c|c|c|c|c|c|c|}
\hline \multicolumn{9}{|c|}{$\begin{array}{l}\text { What percentage of national GDP should the Greek state allocate for mitigation and adaptation } \\
\text { of the climate change? }\end{array}$} \\
\hline \multirow{3}{*}{ GDP percentage } & \multicolumn{4}{|c|}{ Protest Zero bids respondents $(\mathrm{n}=12)$} & \multicolumn{4}{|c|}{ All respondents $(\mathrm{n}=30)$} \\
\hline & \multicolumn{2}{|c|}{$\begin{array}{l}\text { National GDP } \\
\text { at present }\end{array}$} & \multicolumn{2}{|c|}{$\begin{array}{l}\text { National GDP in } \\
25 \text { years }\end{array}$} & \multicolumn{2}{|c|}{$\begin{array}{l}\text { National GDP } \\
\text { at present }\end{array}$} & \multicolumn{2}{|c|}{$\begin{array}{l}\text { National GDP in } \\
25 \text { years }\end{array}$} \\
\hline & $\mathrm{n}$ & $\%$ & $\mathrm{n}$ & $\%$ & $\mathrm{n}$ & $\%$ & $\mathrm{n}$ & $\%$ \\
\hline No contribution & 0 & $0.0 \%$ & 1 & $8.3 \%$ & 0 & $0.0 \%$ & 1 & $3.3 \%$ \\
\hline $0.01 \%$ & 0 & $0.0 \%$ & 0 & $0.0 \%$ & 0 & $0.0 \%$ & 0 & $0.0 \%$ \\
\hline $0.05 \%$ & 0 & $0.0 \%$ & 0 & $0.0 \%$ & 0 & $0.0 \%$ & 0 & $0.0 \%$ \\
\hline $0.1 \%$ & 1 & $8.3 \%$ & 0 & $0.0 \%$ & 2 & $6.7 \%$ & 0 & $0.0 \%$ \\
\hline $0.25 \%$ & 0 & $0.0 \%$ & 0 & $0.0 \%$ & 0 & $0,0 \%$ & 0 & $0.0 \%$ \\
\hline $0.5 \%$ & 4 & $33.3 \%$ & 0 & $0.0 \%$ & 7 & $23.3 \%$ & 0 & $0.0 \%$ \\
\hline $0.75 \%$ & 1 & $8.3 \%$ & 1 & $8.3 \%$ & 2 & $6.7 \%$ & 2 & $6.7 \%$ \\
\hline $1 \%$ & 2 & $16.7 \%$ & 3 & $25.0 \%$ & 4 & $13.3 \%$ & 5 & $16.7 \%$ \\
\hline $1.5 \%$ & 1 & $8.3 \%$ & 0 & $0.0 \%$ & 3 & $10.0 \%$ & 1 & $3.3 \%$ \\
\hline $2 \%$ & 0 & $0.0 \%$ & 2 & $16.7 \%$ & 4 & $13.3 \%$ & 3 & $10.0 \%$ \\
\hline $2.5 \%$ & 0 & $0.0 \%$ & 1 & $8.3 \%$ & 3 & $10.0 \%$ & 3 & $10.0 \%$ \\
\hline $3 \%$ & 1 & $8.3 \%$ & 1 & $8.3 \%$ & 1 & $3.3 \%$ & 4 & $13.3 \%$ \\
\hline $4 \%$ & 1 & $8.3 \%$ & 0 & $0.0 \%$ & 1 & $3.3 \%$ & 6 & $20.0 \%$ \\
\hline $5 \%$ & 1 & $8.3 \%$ & 3 & $25.0 \%$ & 3 & $10.0 \%$ & 5 & $16.7 \%$ \\
\hline Total & 12 & $100 \%$ & 12 & $100 \%$ & 30 & $100 \%$ & 30 & $100 \%$ \\
\hline
\end{tabular}

$60 \%$ of the experts participating in the survey are willing to pay a significant sum to confront climate change impacts (Table 2). However, that sum amounts to a small percentage of the aggregate public contribution proposed by the same experts. Thus, the experts in question are explicitly accepting two distinct valuations of mitigation and adaptation measures. They attempt an individual valuation but, at the same time, they define a public valuation which by far exceeds the individual one. It appears that what the experts are proposing is that climate change mitigation and adaptation measures should both receive public funding that reflects their public value. 
The criticality of 'climate' environmental functions (and, hence, of climate change impacts) as a public asset is reflected in Table 3: 80\% of the experts consider the phenomenon to be important/very important today and $97 \%$ that it will be important/very important in 25 years' time. The increasing criticality of the phenomenon in the future is accompanied by a substantial increase in the public valuation for its confrontation. Table 5 indicates that the public contribution should reach $2.75 \%$ of GDP in 25 years whereas it is currently estimated at $1.71 \%$ of GDP.

Table 5. GDP allocation for present and future mitigation and adaptation costs

\begin{tabular}{l} 
What percentage of the National GDP should the Greek state provic chate \\
mitigation and adaptation of the climate change? \\
\hline Present context \\
Mitigation Total \\
1. Reduction in the demand for carbon-intensive goods and services \\
2. Improved energy efficiency \\
3. Promotion of new, low-carbon technologies \\
4. Investment in renewable energy sources \\
5. Reduction of non- $\mathrm{CO}_{2}$ emissions (land use, farming etc) \\
6. Other (Research - Education)
\end{tabular}

\section{Adaptation Total}

1. Restructuring the economy (new cultivations, eco-tourism, etc.)

2. Infrastructure for protection from natural hazards (floods, droughts, wildfires, etc.)

3. Infrastructure for the creation of new water reservoirs

4. Protection of the natural environment (rivers, threatened species, marine ecosystems, etc.)

5. Establishment of new institutional, regulatory and management structures

6. Reform of the healthcare system

7. Other (Climate change refugees)

TOTAL GDP for mitigation and adaptation

Mean

S.D.

$\%$

GDP

Future context (25 years from now, provided that future policy is identical with present policy)

\section{Mitigation Total}

1. Reduction in demand for carbon-intensive goods and servic

2. Improved energy efficiency

3. Promotion of new, low-carbon technologies

4. Investment in renewable energy sources

5. Reduction of non- $\mathrm{CO}_{2}$ emissions (land use, farming, stockbreeding)

6. Other (Research - Education)

$\begin{array}{lll}\mathbf{1 . 1 3 \%} & \mathbf{1 . 1 2 \%} & \mathbf{6 6 . 1 \%} \\ 0.19 \% & 0.21 \% & 11.1 \% \\ 0.28 \% & 0.38 \% & 16.4 \% \\ 0.20 \% & 0.16 \% & 11.7 \% \\ 0.35 \% & 0.49 \% & 20.5 \% \\ 0.12 \% & 0.14 \% & 7.0 \% \\ 0.02 \% & 0.05 \% & 1.2 \% \\ \mathbf{0 . 5 8 \%} & \mathbf{0 . 6 8 \%} & \mathbf{3 3 . 9 \%} \\ 0.12 \% & 0.14 \% & 7.0 \% \\ 0.10 \% & 0.12 \% & 5.8 \% \\ & & \\ 0.11 \% & 0.13 \% & 6.4 \% \\ 0.12 \% & 0.17 \% & 7.0 \% \\ & & \\ 0.09 \% & 0.11 \% & 5.3 \% \\ 0.05 \% & 0.08 \% & 2.9 \% \\ 0.01 \% & 0.04 \% & 0.6 \% \\ \mathbf{1 . 7 1 \%} & \mathbf{1 . 4 5 \%} & \mathbf{1 0 0 . 0 \%}\end{array}$

\section{Adaptation Total}

1. Restructuring the economy (new cultivations, eco-tourism, etc.)

2. Infrastructure for protection from natural hazards (floods, forest fires, etc.)

$\mathbf{1 . 3 0 \%} \quad \mathbf{0 . 8 8} \% \quad \mathbf{4 7 . 3 \%}$

$0.17 \% \quad 0.14 \% \quad 6.2 \%$

3. Infrastructure for the creation of new water reservoirs

$0.29 \%$

$0.21 \% \quad 10.5 \%$

$0.31 \% \quad 0.28 \% \quad 11.3 \%$

4. Protection of the natural environment (rivers, threatened species, marine

$0.23 \%$

$0.19 \% \quad 8.4 \%$ ecosystems, etc.)

5. Establishment of new institutional, regulatory, and management structures

$0.16 \% \quad 0.16 \% \quad 5.8 \%$

$0.11 \% \quad 0.09 \% \quad 4.0 \%$

6. Reform of the healthcare system

$0.02 \% \quad 0.06 \% \quad 0.7 \%$

7. Other (Climate change refugees)

$2.75 \% \quad 1.55 \% \quad 100.0 \%$ 
Another finding, which is probably the opposite of what is intuitively expected, strongly supports the criticality of climate as well as its public nature and the existence of ethical motives in the valuation. Table 1 indicates that $68.3 \%$ of the individual contributions is allocated to mitigation policies and only $31.7 \%$ to adaptation measures. Similarly, according to Table 5, $1.13 \%$ of GDP should fund mitigation policies and $0.58 \%$ should go towards adaptation strategies. One might expect that both individual and public contributions would be oriented towards adaptation measures that protect the national socio-economic system and national welfare and, hence, the welfare of the experts surveyed. On the contrary, the findings of the research indicate that Greek experts regard as more valuable the national mitigation measures that control the Greek greenhouse emissions and, consequently, prevent deterioration in the global climate. Taking into account that Greece is a small contributor to climate change gases [Greek emissions, were $122.543 \mathrm{Tg}$ in 2009, in other words, $2.7 \%$ of the EU total of $4614.526 \mathrm{Tg}$ (EEA, 2012)], it appears likely that an ethical motivation is behind the allocation of individual and public contributions between mitigation and adaptation measures: instead of protecting themselves from climate change impacts, the experts consider it more valuable to prevent the worldwide public good from deteriorating further.

In conclusion, the existence of the BTS value formulation effect is supported by the findings of the survey with climate experts. The analysis strongly indicates the existence of ethically motivated values for the climate's crucial environmental functions and services. Those ethical values co-exist with individual values which, however, are substantially lower than the corresponding ethically motivated values. In the following section we attempt to explain the phenomenon of the co-existence of ethically motivated values alongside self-interested ones.

\section{Discussion and Concluding Remarks}

The BTS value formulation effect is confirmed by the results of our survey. This confirmation is important since it is expected that experts are better informed in comparison to average citizens. The experts' valuations are less affected by measurement biases (Harris et al., 1989). The elimination of measurement biases is important in a study that seeks to place emphasis on the co-existence of ethical motivated and self-interested preferences through the identification of the BTS effect. Our results indicate that the individual values stated by the experts are much lower than the public values that those experts define for the same goods. Based on these findings we essay to explain the origins of ethical values towards the protection of crucial environmental functions and services.

The experts consider that the impact of climate change represents a major threat to public welfare. Therefore, climate change impacts must be confronted with appropriate mitigation and adaptation policies. Experts, acting as self-interested individuals, are willing to pay a significant amount for the appropriate policies. This amount emerges as a 'fair share' contribution for the protection of a significant public good. However, applying such a survey only to experts leads to methodological shortcomings and limitations. In order to estimate comprehensively and reveal the preferences of the society this survey should be redesigned and applied to a representative sample of the total population.

On the other hand, the ethically motivated valuation indicates that individual contributions lag behind the amount necessary to protect society's welfare from climate change impacts. Climate policy is a public initiative and requires public financial contribution. Climate functions and services and, therefore, climate policies contribute to the welfare of society in a significant way. Furthermore, climate functions are an important factor in the wellbeing of future generations. The preservation of such crucial public environmental functions should receive public funds. Individuals could contribute to these funding schemes by a 'fair share' which is determined by their 'time span' and 'space span' effects (Bithas, 2011). The time span effect is determined by the expected lifetime of an individual plus a period covering the lifetime of direct descendants. The space span effect is defined by the geographical area that is related functionally to the welfare of an individual. The area within individuals perceive their welfare is extremely limited in comparison to the geographical dimensions of climate change impacts which cover the ecosystem of the Earth in its entirety.

The co-existence of ethically motivated values with self-interested ones may well be explained by the institutional context of western societies, in which the 'marketization' of every sphere of social life is extensively promoted. Traditional public spheres of life, actions, and goods are constantly pressed towards 'marketization'. In that institutional setting, the so-called 'self-interested rational consumer' is the dominant prototype. Adhering to that contemporary social prototype, individuals are willing to pay to preserve public environmental goods and environmental functions. On the other hand, the contemporary ideological prototype cannot eliminate the fundamental properties of crucial environmental goods and functions, which are irrevocably public and directly concern the welfare potential of the current and future generations. Under those conditions and if they are to be effective, the appropriate preservation schemes inevitably acquire public dimensions. Although individual valuations can be substantial, they cannot be but a 'fair share' of the aggregate social value of crucial public 
environment assets and functions. Therefore, individual valuations are not the appropriate guide for effective environmental policies.

The empirical findings of our study support a prototype citizen who, in the case of climate change, acts according to a rationale not predicted by economics. Informed citizens hold ethical social commitments that result in attributing significant public values that far exceed the self-interested values. Strategies for crucial environmental functions should recognize the existence of social values and include them in the policy-making process. Crucial environmental functions determine the welfare of all future generations and, therefore, may be evaluated in a way that overcomes the individualistic, egoistic prototype. When they can be estimated, social values offer an indicator for climate change policies.

\section{References}

Adamowicz, W. L., Bhardwaj, V., \& Macnab, B. (1993). Experiments on the difference between willingness to pay and willingness to accept. Land Economics, 69, 416-427. http://dx.doi.org/10.2307/3146458

Ami, D., Aprahamian, F., Chanel, O., Joulé, R. V., \& Luchini, S. (2014). Willingness to pay of committed citizens: A field experiment. Ecological Economics. http://dx.doi.org/10.1016/j.ecolecon.2014.04.014

Bergson, A. (1938). A reformulation of Certain Aspects of Welfare Economics. Quarterly Journal of Economics, 52, 310-334. http://dx.doi.org/10.2307/1881737

Bergstrom, J. C., Stoll, J. R., \& Randall, A. (1990). The impact of information on environmental commodity valuation decisions. American Journal of Agricultural Economics, 72, 614-21. http://dx.doi.org/10.2307/124 3031

Bergstrom, T., Blume, L., \& Varian, H. (1986). On the private provision of public goods. Journal of Public Economics, 29, 25-49. http://dx.doi.org/10.1016/0047-2727(86)90024-1

Berrens, R. P., Bohara, A. K., Jenkins-Smith, H. C., Silva, C. L., \& Weimer, D. L. (2004). Information and effort in contingent valuation surveys: application to global climate change using national Internet samples. Journal of Environmental Economics and Management, 47, 331-363. http://dx.doi.org/10.1016/S0095-0696(03)000 94-9

Bishop, R. C., \& Heberlein, T. A. (1979). Measuring values of extra-market goods: are indirect methods biased? American Journal of Agricultural Economics, 61, 926-930. http://dx.doi.org/10.2307/3180348

Bithas, K. (2011). Sustainability and externalities: Is the internalization of externalities a sufficient condition for sustainability?. Ecological Economics, 70(10), 1703-1706. http://dx.doi.org/10.1016/j.ecolecon.2011.05.014

Braden, J. B., \& Kolstad, C. D. (1991). Measuring the demand for environmental quality. North-Holland, Amsterdam.

Brown, C. T., \& Gregory, R. (1999). Why the WTA-WTP disparity matters. Ecological Economics, 28, 323-335. http://dx.doi.org/10.1016/S0921-8009(98)00050-0

Cameron, T. (2004). Individual option prices for climate change mitigation. Journal of Public Economics, 89 , 283-301. http://dx.doi.org/10.1016/j.jpubeco.2004.01.005

Coursey, D. L., Hovis, J. L., \& Schulze, W. D. (1987). The Disparity between Willingness to Accept and Willingness to Pay Measures of Value. The Quarterly Journal of Economics, 102(3), 679-690. http://dx.doi.org/10.2307/1884223

EEA. (2012). EEA greenhouse gas - data viewer. European Environmental Agency. Retrieved from http://www.eea.europa.eu/data-and-maps/data/data-viewers/greenhouse-gases-viewer

Fleischer, A., \& Sternberg, M. (2005). The economic impact of global climate change on Mediterranean rangeland ecosystems: A Space-for-Time approach. Ecological Economics, 59, 287-295. http://dx.doi.org/10.1016/ j.ecolecon.2005.10.016

IPCC. (2013). Fifth Assessment Report, WGI-Climate Change 2013: The Physical Science Basis. Intergovernmental Panel on Climate Change.

Kahneman, D., Knetsch, J. L., \& Thaler, R. H. (1990). Experimental tests of the endowment effect and the Coase theorem. Journal of Political Economy, 98, 1325-1348. http://dx.doi.org/10.1086/261737

Karr, J. R. (1991). Biological integrity: a long-neglected aspect of water resource management. Ecological Applications, 1(1), 66-84. http://dx.doi.org/10.2307/1941848 
Knetsch, J. L. (1995). Asymmetric valuation of gains and losses and preference order assumptions. Economic Inquiry, 33, 134-14. http://dx.doi.org/10.1111/j.1465-7295.1995.tb01851.x

Kohn, R. E. (1993). Measuring the existence value of wildlife: Comment. Land Economics, 69, 304-308. http://dx.doi.org/10.2307/3146596

Kolstad, D. C., \& Guzman, M. R. (1999). Information and the divergence between willingness to accept and willingness to pay. Journal of Environmental Economics and Management, 38, 66-80. http://dx.doi.org/10. 1006/jeem.1999.1070

Layton, D. F., \& Gardner, B. (2000). Heterogeneous preferences regarding global climate change. Review of Economics and Statistics, 82, 616-624. http://dx.doi.org/10.1162/003465300559091

Mac Donald, H. F., \& Bowker, J. M. (1994). The endowment effect and WTA: a quasi-experimental test. Agricultural and Applied Economics, 26(2), 545-551.

Neumayer, E. (2007). A missed opportunity: The Stern Review on climate change fails to tackle the issue of non-substitutable loss of natural capital. Global Environmental Change, 17(3-4), 297-301. http://dx.doi.org/10.1016/j.gloenvcha.2007.04.001

Nordhaus, W. D. (2008). A review of the Stern Review on the economics of climate change. Journal of Economic Literature, 45(3), 686-702. http://dx.doi.org/10.1257/jel.45.3.686

Nyborg, K. (2000). Homo economics and homo politicus: interpretation and aggregation of environmental values. J. Econ. Behav. Organ, 42, 305-322. http://dx.doi.org/10.1016/S0167-2681(00)00091-3

Parks, S., \& Gowdy, J. (2013). What have economists learned about valuing nature? A review essay. Ecosystem Services, 3, 1-10. http://dx.doi.org/10.1016/j.ecoser.2012.12.002

Peterson, S. (2011). Socrates and philosophy in the dialogues of Plato. Cambridge University Press. http://dx.doi.org/10.1017/CBO9780511921346

Riera, P., Peñuelas, J., Farreras, V., \& Estiarte, M. (2007). Valuation of climate-change effects on mediterranean shrublands. Ecological Applications, 17, 91-100. http://dx.doi.org/10.1890/1051-0761(2007)017 [0091:VOCEOM]2.0.CO;2

Rockström, J., Steffen, W., Noone, K., Persson, Å., Chapin, F. S., Lambin, E., ... Foley, J. (2009). Planetary boundaries: exploring the safe operating space for humanity. Ecology and Society, 14(2), 32.

Samuelson, P. A. (1977). Reaffirming the existence of 'reasonable' Bergson-Samuelson social welfare functions. Economica, 44, 81-88. http://dx.doi.org/10.2307/2553553

Samuelson, P. A. (1981). Bergsonian welfare economics. In S. Rosefielde (Ed.), Economic Welfare and the Economics of Soviet Socialism: Essays in Honor of Abram Bergson (pp. 223-266). Cambridge University Press. http://dx.doi.org/10.1017/CBO9780511895821.011

Spash, C. L. (2000). Multiple value expression in contingent valuation: economics and ethics. Cambridge Research for the Environment-Department of Land Economy University of Cambridge.

Spash, C. L. (2007). The economics of climate change impacts à la Stern: Novel and nuanced or rhetorically restricted? Ecological Economics, 63(4), 706-713. http://dx.doi.org/10.1016/j.ecolecon.2007.05.017

Spash, C. L., \& Hanley, N. (1995). Methodological and ideological options- preferences, information and biodiversity preservation. Ecological Economics, 12, 191-208. http://dx.doi.org/10.1016/0921-8009 (94)00056-2

Stern, N. (2007). The economics of climate change: The Stern Review. Cambridge University Press. http://dx.doi.org/10.1017/CBO9780511817434

Sterner, T., \& Persson, U. M. (2007). An even Sterner Review: introducing relative prices into the discounting debate. Discussion paper 07-37. Resources for the Future. Washington DC.

Stevens, T. H., Echeverria, J., Glass, R. J., Hager, T., \& More, T. A. (1991). Measuring the existence of value of wildlife: What do CVM estimates really show? Land Economics, 67, 390-400. http://dx.doi.org/10.2307/3146546

Stevens, T. H., More, T. A., \& Glass, R. J. (1993). Measuring the existence value of wildlife: Reply. Land Economics, 69, 309-312. http://dx.doi.org/10.2307/3146597 
Sugden, R. (2005). Coping with preference anomalies in cost-benefit analysis: A market simulation approach. Environ. Resour. Econ., 32, 129-160. http://dx.doi.org/10.1007/s10640-005-6031-5

Tintner, G. (1946). A note on welfare economics. Econometrica, 14, 69-78. http://dx.doi.org/10.2307/1905704

Tol, R. S. J. (2005). The marginal damage costs of carbon dioxide emissions: an assessment of the uncertainties. Energy Policy, 33, 2064-2074. http://dx.doi.org/10.1016/j.enpol.2004.04.002

Tol, R. S. J. (2009). The Economic Effects of Climate Change. Journal of Economic Perspectives, 23(2), 29-51. http://dx.doi.org/10.1257/jep.23.2.29

Toman, M. (2006). Values in the economics of climate change. Environmental Values, 15(3), 365-379. http://dx.doi.org/10.3197/096327106778226310

Van Houtven, G., Mansfield, C., Phaneuf, D. J., von Haefen, R., Milstead, B., Kenney, M. A., \& Reckhow, K. H. (2014). Combining expert elicitation and stated preference methods to value ecosystem services from improved lake water quality. Ecological Economics, 99, 40-52. http://dx.doi.org/10.1016/j.ecolecon. 2013.12.018

Van Kooten, G. C., \& Schmitz, A. (1992). Preserving Waterfowl Habitat on the Canadian Prairies: Economic Incentives vs. Moral Suasion. American Journal of Agricultural Economics, 74(1), 79-89. http://dx.doi.org/10.2307/1242992

Vatn, A., \& Bromley, D. W. (1994). Choices without prices without apologies. Environmental Economics and Management, 26, 129-148. http://dx.doi.org/10.1006/jeem.1994.1008

Weitzman, M. L. (2008). A review of the Stern Review on the economics of climate change. Journal of Economic Literature, 45(3), 703-724. http://dx.doi.org/10.1257/jel.45.3.703

Whitehead, J. C., \& Blomquist, G. C. (1991). Measuring Contingent Values for Wetlands: Effects of Information about Related Environmental Goods. Water Resources Research, 27(10), 2523-2531. http://dx.doi.org/10. 1029/91WR01769

Woodruff, P. (2010). Plato's shorter ethical works: Crito the Stanford encyclopedia of philosophy. The Metaphysics Research Lab, Stanford University.

\section{Copyrights}

Copyright for this article is retained by the author(s), with first publication rights granted to the journal.

This is an open-access article distributed under the terms and conditions of the Creative Commons Attribution license (http://creativecommons.org/licenses/by/3.0/). 